\title{
10 Ecofeminism avant la Lettre
}

\author{
Chen Jingrong and Baudelaire \\ Liansu Meng
}

\begin{abstract}
This essay reveals how Chen Jingrong realizes the translator's agency in strikingly original ways in her influential mid-twentieth-century renditions of Baudelaire, and how Chen's translations are intertwined with her development of an eco-feminist poetics avant la lettre. Against the backdrop of modern China's tumultuous, politicized encounters with foreign literatures, it highlights Chen's personal trajectory as a female author in a pervasively male-dominated literary field.
\end{abstract}

Keywords: Chinese poetry, translation, Chen Jingrong, Baudelaire, ecofeminism, women translators

Ever since its emergence in the early twentieth century, modern Chinese poetry has been inseparable from the translation of foreign poetry. Many Chinese poets were translators themselves. Arguably, as translators, their primary purpose was to inspire new ways of writing Chinese poetry; and as such, their approach leads to easy association with recent trends of viewing translation as creative writing and recognizing the translator's agency as key to the complex process of translation (Perteghella and Loffredo 2007; Rosario 2012; Babaee 2016).

Among countless poets translated into Chinese, Charles Baudelaire (1821-1867) appears unique for his inexhaustible capacity to inspire successive generations of Chinese poets, from the first translations of his work a hundred years ago to the present day. ${ }^{1}$ Chinese poets and translators have

1 Zhou Zuoren 周作人 (1885-1967) was likely the first Chinese translator of Baudelaire. He first translated Baudelaire's poem “Get Drunk" (Enivrez-vous) in 1918 (Bien 2013, 41) and acknowledged

Van Crevel, Maghiel and Lucas Klein (eds.), Chinese Poetry and Translation: Rights and Wrongs. Amsterdam: Amsterdam University Press, 2019 DOI: 10.5117/9789462989948_CH10 
often followed Western critics and hailed Baudelaire as a representative of Symbolism, as a Satanist, Decadent, and dandy. They have emulated his poetic forms, his use of synesthesia, and his poetic transformation of the dark and ugly. Notably, Baudelaire's zealous Chinese followers have remained mostly a men's club, and they have sometimes interpreted and celebrated his misogynist depictions of women as gestures of rebellion against traditional constrictions on sexuality (Zhang 2009, 77-92; Bien 2013, 55-74). This emphasis on poetic technique and insensitivity to issues of gender equality have been prevalent in the male-dominated field of Chinese poetry at large (see van Crevel 2017, pars. 13-18).

Chen Jingrong 陈敬容 (1917-1989) stands out not only as one of the era's few recognized female poets, but also as the only female among several dozen Chinese translators of Baudelaire. Moreover, her translations count as a legendary inspiration of underground (地下) poetry in the 196os and 1970s, during the Cultural Revolution. Many of the authors in question, especially the ground-breaking Misty Poets (朦胧诗人, sometimes also rendered as "Obscure Poets"), recall their encounters with Baudelaire's poetry through Chen's translations as a defining moment. Yet, despite their acknowledgement of her work, younger generations of Chinese poets have generally regarded Chen as a transparent transmitter of Baudelaire's poetry into Chinese, without registering awareness of her agency as a poet-translator and her unique interpretation of Baudelaire's poetry (Ling 2004, 269; Bei Dao 2005, 86; Liang 2006; Tamburello 2012, 21-46; Bai Hua 2012; Liu 2015).

Tracing back to the 1940s, when Chen first translated and published on Baudelaire's poetry, the present essay examines how she developed a prescient ecofeminist poetics in the male-dominated, culturally and politically repressive literary fields of Shanghai in the 1940s and Beijing in the 1950s, in her translations as in her own poetry - which was clearly influenced by her engagement with Baudelaire. Obviously, Chen's work predates theories of ecofeminism, feminist translation (Palacios 2014; Palmary 2014), feminist critiques of Baudelaire's misogyny (Weinbaum 2003), and discussions of his eco-awareness (Quandt 2015) in recent decades. However, her early immersion in feminist ideals and her personal experience of oppression in a male-dominated society that was rapidly industrializing enabled her to see the interconnectedness of the oppression of women and other marginalized groups such as the poor, the aged, and the sick, on the one hand, and the destruction of nature, on the other. 
Where the analysis draws on English translations of Baudelaire to date, I will refer to Francis Scarfe's (1986) and Keith Waldrop's (2006) renditions. This is because my analysis of Chen's translations focuses on thematics and imagery rather than prosody, and both Scarfe and Waldrop render Baudelaire's poetry as prose and privilege content over form. All English translations from the Chinese, including the English translations of Chen's Chinese renditions of Baudelaire, are mine.

\section{Chen's early representations of Baudelaire}

Chen started reading French poetry extensively when studying French with a tutor in Beijing in fall 1936 (Chen 1984, 2-3; Luo and Chen 2008, 738). She first translated poetry by Baudelaire in 1945, after fleeing her oppressive marriage with Sha Lei 沙蕾 (1912-1986), another Chinese poet, and settling down in Chongqing, the capital of the territory controlled by the Nationalist Party (KMT) during the Second Sino-Japanese War (1937-1945). Supported by her brother and friends, Chen enjoyed a short period of peace and freedom as she was translating French poetry, including a dozen poems by Baudelaire, while also writing her own poetry and essays (Luo and Chen 2008, 729). In 1946 Chen moved to Shanghai, the largest cultural, commercial, and industrial metropolis in China at the time, and started one of the most prolific periods of her literary career (729-731).

To appreciate the significance of Chen's poetics and her interpretation of Baudelaire, it is necessary to understand certain features of the local literary field at the time. The Sino-Japanese war had ended in August 1945, but the civil war between the Chinese Communist Party (CCP) and the KMT had resumed. Ever since 1942, when Mao Zedong 毛泽东 gave his well-known “Talks at the Yan'an Forum on Art and Literature” (在延安文 艺座谈会上的讲话), the CCP had taken the position that literature should be subordinate to politics and use the language of "the masses" to promote the goals of revolution and national survival (Denton 2016).

In KMT-controlled areas, including Shanghai, the CCP's influence permeated many institutions through its underground organization. Consequently, the poetic field in Shanghai was dominated by "People's Poetry" (人民诗歌), a sloganistic political poetry advocating “revolutionary realism" (革命现实 主义) and supposedly catering to the taste of "the masses" (You 1997, 41-42; Jiang 2002, 78-87). It was under these circumstances that Chen published her essay “Baudelaire and the Cat” (波德莱尔与猫) on December 19, 1946 - and that she suffered harsh criticism of her Baudelaire translations and her 
own poetry from an all-male group of leftist critics (You 1997, 42-52). Their criticism was not targeted at Chen's poetry or the quality of her translations per se, but at what they considered Chen's ill-timed decision to translate, emulate, and praise Baudelaire. His style and themes did not fit the needs and standards of "People's Poetry."

Lin Huanping 林焕平, the first to attack Chen, argued that Baudelaire's poetry did not serve the taste of the masses (1946). Li Baifeng 李白凤 criticized Chen's own recent poetry as "Baudelairean," expressing the "fragile sentiments of the petite bourgeoisie or intellectuals in decline." Li condemned "Mr. Chen's" poetry for being "divorced from reality," thus doomed to be "discarded by the masses" $(1947,7)$. Tie Ma 铁马 suggested that "he," meaning Chen, operated "at a distance from our surging times and complex reality" (1946). Li, Tie Ma, and other critics' references to Chen in masculine terms can signal an unexamined assumption that Chen was a man, or else a gesture of deference to an accomplished female author. Either way, it demonstrates how the category of gender had been eclipsed by male-dominated discourses of nation, revolution, and class, in the literary field as in society at large.

On February 7, 1947, in response to her critics, Chen published another essay, “On My Poetry and Poetry Translation” (谈我的诗和译诗) (1947, 7). Different from Chen's erstwhile critics, I hold that her two essays show that her decision to "praise" Baudelaire was not an ill-advised blunder that proved she was out of touch with reality. On the contrary, the essays critique the then prevalent People's Poetry's obliviousness to the pain and suffering of underprivileged groups; and through Chen's reading of Baudelaire from an original, feminist perspective, they articulate a prescient and sophisticated ecofeminist poetics avant la lettre.

"Baudelaire and the Cat" opens with a laconic, one-line paragraph, foregrounding a distinctly personal perspective rather than assuming the tone of "objective" literary analysis: "Baudelaire often makes me think of a cat." Baudelaire wrote a number of cat poems, but the cat was not among his major themes, and has not been identified as such to my knowledge. In the historical setting of Chen's essays, where a highly politicized solemnity and grandiosity held sway, using this image constituted a bold move. The essay's second paragraph is also a single sentence in the source text, now an observation on Baudelaire's self-portrait: "two bright eyes, mixing a scorching heat and an icy coldness; his facial lines blending hardness and softness, all this resembles a cat" (1946b). In both Baudelaire's portrayal and that of the cat, Chen highlights a sharp vision and a sense of the compatibility of opposites. 
Further elaborating the image of the cat, Chen caustically contrasts her ideas with a Darwinian vision of monkeys and humans:

Except for monkeys (according to Darwin's theory, the more advanced among them have long evolved into humans, and some have today evolved to the point of knowing how to slaughter their own kind for pleasure), the smartest of all animals may be the cat. A full body of soft fur, four nimble feet, a pair of sharp eyes, its meowing sounds sometimes warm, sometimes bleak, sometimes so fierce it gives mice the shivers.

(1946b)

Social-Darwinian notions of evolution and progress had been widely embraced by Chinese intellectuals since their introduction into China at the turn of the twentieth century (Song 2015, 34-36, 96-97). Contrary to her predecessors and contemporaries, Chen points out the irony and invalidity of these notions in the brutal reality of war: humans, supposedly the most advanced species, have not evolved into better versions of themselves, but are un-empathetic, savage, and cruel to their own kind, to say nothing of what they do to other creatures. On the other hand, Chen's characterization of the cat - as a complex creature that combines the qualities of gentleness and sharp-eyed vision with the capacity to experience wide-ranging emotions such as warmth, sadness, and fierceness - underscores her ecofeminist emphasis on empathy, a vision that resonates with today's ecofeminism (Gaard 2016, 169). ${ }^{2}$

Chen subsequently turns to European Romanticism, of which she offers a rather conventional picture - but a closer look shows that this serves as a springboard to her highly original interpretation of Baudelaire's poetics. She attributes the decline of Romanticism to the "exaggeration" and "emptiness" of "Romantic passion" and applauds Baudelaire as harbinger of the (Symbolist) new generation by being the first to "hurl the miracle of deep emotions and prescient wisdom into French poetry" (1946b). Significantly, Chen's disparagement of Romanticism can be read as a critique of the People's Poetry that dominated the local literary environment.

Chen then reiterates commonly held views on Baudelaire's poetry, commending its rich colors and musicality, but swiftly shifts to an interpretation from her own perspective. She characterizes Baudelaire as a poet who feels equal empathy for all things, especially "minor and small things," which "he

2 Obviously, what matters here is not most people's general ideas about cats and empathy, but how Chen Jingrong chose to portray the cat. 
paints ... with a layer of miraculous radiance." She highlights the "genuineness and profundity" of Baudelaire's emotions and thoughts as reflected in his poetry, opposing these to the "superficiality and exaggeration" she observes in European Romanticism. She attributes the reason for the quality of his poetry to its origin in "the depth of his emotions and intellect," which in turn "originate from real life" (1946b). The weight of the paragraph falls on the emphasis on "real life," meaning lived experience.

Chen further clarifies the connection between "real life" and a poetics of empathy by juxtaposing Baudelaire's dismal life experience with his empathy for the unfortunate and underprivileged, the powerless and vulnerable:

Baudelaire was a true lover of life. He lived a bleak life and had an odd temperament. He loved many things that others never loved, and he wrote about them with a kind touch. He voiced grievances for all the unfortunate in the crowd: the poor, the handicapped, ugly women, widows, orphans, even lost birds and homeless dogs. He loved clouds, storms, the sea, the scorching sun and the icy moon; he also loved a tiny flower and a minuscule pipe. He also loved cats.

(1946b)

The spectrum of Baudelaire's empathy, as Chen sees it, spans across class, physical ability, physical appearance, marriage and family relations, and age; it extends to animals, the natural environment, and inanimate objects, a view with clear interfaces with today's ecofeminism. As Sam Mickey notes, the point of ecofeminism is to focus on "interconnections and networks of coexistence, which include the entangled categories of race, class, age, ability, religion, nationality, ethnicity, and many others, along with species, gender and sexuality" (2018, xvii). To my knowledge, no other poets or scholars have interpreted Baudelaire's poetics this way. Chen's characterization of Baudelaire is different from, and indeed almost the opposite of, that of most of the male Chinese poets who were inspired by Baudelaire's poetry - and who often celebrated him as a rebel against tradition because of his reputation as a Satanist, Decadent, and dandy (Zhang 2009, 77-92; Bien 2013, 66-69). In fact, Chen's encapsulation of Baudelaire in this passage is a disguised pronouncement of her own ecofeminist poetics, which views the world from the perspective of, and shows equal empathy to, all vulnerable beings in the world.

Conscious of her unusual approach to Baudelaire's poetics, Chen emphasizes the reader/interpreter's active use of their agency. She advocates "looking for" the positive side and "discovering" the ingenuity in Baudelaire's works. She defies commonly held views of Baudelaire as "decadent" and 
identical to other Symbolist poets such as Mallarmé, by highlighting Baudelaire's different class background and poetics. To end her essay, she quotes her fellow female poet Zheng Min 郑敏 (b. 1920): "One can only let more pain heal / those hurting wounds," and emphasizes the paradoxical, soothing power of literary works that treat of pain and sadness (1946b). Baudelaire and Zheng Min, different poets from different worlds, become unlikely allies, both marshaled in the support of Chen's ecofeminist poetics.

In "Baudelaire and the Cat," Chen does not explain her motives for advocating for such empathy with the suffering of the vulnerable, but her second essay, "On My Poetry and Poetry Translation," published less than two months later, offers a clue. The essay rebukes her critics' accusations that she was emulating and imitating Baudelaire, and thus out of touch with reality. Strikingly, in what was a bold move in her day, she foregrounds her identity as a woman, associating her individual suffering with the universal oppression of women:

I have written a lot in the past two years [1945-1946] mainly because I have finally walked out of an oppressive domestic life (it is not hard to imagine how torturing the narrow domestic life is for Chinese women). Besides, the experience of leaving the depression-ridden Lanzhou behind and beginning to face the wide expanse of society has further strengthened my yearning for a bright future and boosted my passion for writing. ...

Chinese women have suffered all kinds of oppression in the millennialong feudal tradition. Until today, no fully reasonable solutions have been reached for social, financial, or many other issues, even though the equality of men and women has been recognized in principle. Women still suffer from stifling oppression. Therefore, we have an all the more urgent yearning for a just life in the future, for truth, justice, and light, and an all the deeper resentment for the feudal tradition and all kinds of unjust conditions.

(1947)

This is the only time that Chen publicly and explicitly links the impediment of her literary pursuits by the literary men closest to her - something to which she repeatedly alludes in her poetry - to a critical social issue that was seen to have no place in public discourse. While the dominant narrative claimed that women's liberation had been achieved and/or was included in society's modern negotiation of nation, revolution, and class, Chen draws on her own experience to show that the oppression of women persisted 
not only in traditional families but also in new-style families that claimed marriage should be a function of romantic love and in society at large. What is more, her insight into the complexity of the issue of gender equality enabled her to perceive "all kinds of unjust conditions," a phrase which recalls her emphasis on "all the unfortunate" in her encapsulation of Baudelaire's poetics; and contrary to her male contemporaries and predecessors' frequent descriptions of Chinese women as helpless victims of oppression, Chen makes the case for women's agency and their empathy for one another and for others, an empathy that is born of suffering. She argues that the endless oppression of Chinese women enables them to urgently and sensitively critique this and other injustices in the world - a view which echoes her reading of Baudelaire's poetics as a poetics of empathy and her association of Baudelaire with Zheng Min.

\section{Chen's translations and her own poetry}

In 1946-1947, Chen translated and published a number of poems by Baudelaire in newspapers in Shanghai and Beiping (now Beijing). These included "Spleen" (Spleen), "Man and the Sea" (L'homme et la mer), "The Living Torch" (Le Flambeau vivant)," "Evening Harmony” (Harmonie du soir), "Music" ("La Musique), and "The Blind" (Les Aveugles) (Zhang 2009, 82). Selected by Chen, all these poems share a thematic of pain, suffering, sadness, and perplexity, as the leftist critics noticed. What they failed to notice was the speaker's persistent search and struggle for a way out of the gloomy condition that Chen accentuated in her translations.

"Music" perfectly demonstrates Chen's active use of her agency as a poet-translator and shows how she molds her poetics into her translations - through modifications and witting or unwitting mistranslations, among other things. The French source text reads,

La musique souvent me prend comme une mer!

Vers ma pâle étoile,

Sous un plafond de brume ou dans un vaste éther,

Je mets à la voile;

La poitrine en avant et les poumons gonflés

Comme de la toile

J'escalade le dos des flots amoncelés

Que la nuit me voile; 
Je sens vibrer en moi toutes les passions

D'un vaisseau qui souffre;

Le bon vent, la tempête et ses convulsions

Sur l'immense gouffre

Me bercent. D'autres fois, calme plat, grand miroir

De mon désespoir!

(Scarfe 1986, 149)

Waldrop's translation reads,

Music often takes me as does a sea! I set sail toward my pale star, under a ceiling of fog or through the vast ether.

Chest out, lungs filled like sails, I scale the backs of banked waves which the night hides from me.

I feel in me the throb of all the passions ships can suffer. Good wind, storm, convulsions

above the yawning gulf - they lull me. At other times: flat calm, great mirror of my despair!

(2006: 91)

Chen's Chinese translation reads,

\author{
音乐有时飘我去, 像大海! \\ 向着我的苍白的星星， \\ 在雾䨠中或是朗空下 \\ 我开始航行。 \\ 胸挺着, 肺张开着 \\ 如像船帆 \\ 我攀上堆叠的水波, \\ 黑夜遮着我。 \\ 我感到热情在体中颤动 \\ 如水之起伏; \\ 大风, 暴雨, 带着骚动
}




\section{在无边的深渊 \\ 摇着我。一有时又水面波静如一面大镜, \\ 照着我失望的悲哀!}

$(1946 a)$

Chen keeps Baudelaire's original sonnet form in terms of the number of lines and their division in stanzas, and follows his indentations, punctuations, and line breaks. Unlike the other poems Chen published at the same time, the translation also stays close to the source text's rhyme scheme. Interestingly, several mistranslations end up enhancing the speaker's agency and illuminating the ecofeminist poetics Chen lays out in "Baudelaire and the Cat."

The most obvious moment occurs in ll. 3-4 of the second stanza. The stanza depicts the speaker imagining riding the sea at night, like a vessel sailing. Both Scarfe's and Waldrop's translations show that the night's darkness prevents the speaker from seeing the huge waves they are riding, thus indicating that the speaker is at risk of falling to their death from this great height (Scarfe 1986, 149; Waldrop 2006, 91). The darkness is depicted as a negative power preventing the speaker from achieving the freedom they seek. Chen, however, turns this negative, hindering power into a positive, empowering ally. In her version, the darkness shields the speaker from being seen, enabling them to enjoy the pursuit of freedom: "I climb the piling waves, / The dark night shielding me."

The third stanza continues the metaphor of the speaker as a ship on the wild sea at night. In ll. 1-2, the speaker's passions are likened to the motion of the ship being rocked by the waves, which must be contained in order for the ship to stay afloat. Scarfe's and Waldrop's translations convey the pain of this struggle. Scarfe writes, "I feel all the passions of a groaning ship vibrate within me" (149). Waldrop writes, "I feel in me the throb of all the passions ships can suffer" (91). Chen's translation eliminates this pain and the conflict. The passions, rather than being contained as a source of suffering, are celebrated as an expression of excitement over the thrilling if dangerous pursuit of freedom. The ocean's waves become an embodiment of the speaker's vibrating passions: "I feel my passions vibrating within my body / Like the undulations of water."

In the penultimate and final stanzas, Chen writes:

$\cdots$

Strong wind, torrential rain, with restlessness

In the infinite abyss

Rock me. - Sometimes the waves are still like a big mirror

Reflecting the sorrow of my disappointment. 
By adding a dash in 1.2 of the final stanza, Chen creates a visual break in the poem. The rest of the stanza depicts a moment of calm on the sea and the speaker's corresponding emotion. Both Scarfe and Waldrop choose the obvious English equivalent to translate the source text's last word, "désespoir," thus portraying the placid sea as a reflection of the speaker's "despair." Chinese also has a direct equivalent, 绝望, which many of Baudelaire's translators use (Dai 1983, 134; Bian 2000, 209; Wen 2007, 177). Chen, however, makes a radical change vis-à-vis the source text and translates “désespoir” as 失望的悲哀 'the sorrow of disappointment', thus erasing the sense of hopelessness while preserving the sense of sadness. The addition of "disappointment" seems to come out of the blue. However, considering Chen's erasure of the emotional conflicts in Baudelaire's speaker and her celebration of their pursuit of freedom in the preceding lines, "disappointment" can be read to echo the break embodied in the dash and to function as a counterpoint to the hopeful excitement experienced by the speaker up to this point. In all, this hints at the preservation of hope and the possibility of future attempts at pursuing freedom.

Chen's sensitivity to the agency of the speaker and her ecofeminist worldview are also evident in her own poetry of the time. In "On My Poetry and Poetry Translation," she cites several of her own poems to refute the charge that her poetry was divorced from reality. One of these poems, "The Inferno Tango" (地狱的探戈舞), exemplifies Chen's ecofeminist critique of injustice, including nuclear warfare. The poem presents a dramatic monologue with the speaker addressing a silent "you," delivering a scathing, ironic critique of the callous nature of "your" beliefs:

\author{
假若我相信月亮会跳跃 \\ 石头会唱歌 \\ 你会流泪 \\ 假若我相信原子弹 \\ 只是另一世界的谷粒 \\ 暴戻是爱的果子 \\ 假若盐失掉了盐味 \\ 会变得比糖更甜蜜 \\ 假若感情是条一鞭子 \\ 生活是一阵雷 \\ 假若整个世界只是 \\ 可以任你信足一踢的足球
}




\section{那末当鸱系狞笑的午夜 \\ 跳起地狱的探戈舞吧 \\ 它将会带给你 \\ 一个比夜更黑的白昼}

3.1.

(Luo and Chen 2008, 136)

Here is "Inferno Tango" in my translation:

Let's say I believe the moon can leap

Stones can sing

You can weep

Let's say I believe atomic bombs

Are just grain kernels from another world

And tyranny the fruit of love

Let's say salt is sweeter than sugar

After losing its saltiness

Let's say feelings are a whip

And life a peal of thunder

Let's say the whole world is just

A rubber ball you can casually kick

Then when the owls laugh hideously at midnight

Dance the inferno tango!

It will bring you

A day darker than night

- March 1

In the first stanza, by first offering two impossible suppositions (that the moon can leap and stones can sing), the speaker implies that their third supposition (that "you" can weep) is equally impossible. But why should "you" be incapable of crying? It helps to read this in the context of the People's Poetry that was prevalent at the time: its advocates believed that poetry should convey the utmost optimism and upbeat passion for revolution and national survival - so shedding tears, taken as a sign of weakness and pessimism, was out of the question. The speaker, however, sees "your" inability to shed tears as an absurdity rather than a sign of strength and power. The following stanzas show that the speaker aligns "your" inability 
to cry with self-centered callousness, cruelty, and a lack of concern and compassion for others and for the world at large.

In the second stanza, the speaker, continuing to juxtapose common-sense statements with the harsh reality of the time, opens with an ominous, apparently nonsensical supposition about nuclear warfare. Written six months after the US military dropped two atomic bombs on Hiroshima and Nagasaki, ending World War II and the eight-year Japanese invasion of China, the poem offers an unusual perspective. While most people were celebrating the defeat of the Japanese military, the speaker calls attention to the self-centered callousness inherent in viewing the bombs as mere otherworldly "grain kernels" - an image normally associated with an ordinary source of basic nutrition and growth but easily associable with the bombs on account of their conical shape - and normalizing and minimizing their terrible impact on countless innocent people's lives.

The speaker offers a second impossible supposition in this stanza, when they reject the bizarre idea that despotic violence is produced by love. In the context of the war, the violence committed against Japanese lives through the atomic bombs was widely justified and celebrated as an act of love for the peace and safety of the rest of the world. For the speaker, however, a compartmentalized vision that pits the strong and victorious against the vulnerable and defeated is as nonsensical as believing that salt can lose its saltiness.

The third stanza continues the juxtaposition of violence and love but offers a chilling depiction of "your" self-obsessed, callous view of the world as just an expendable toy, as though "you" were not part of the world and would not be impacted if it were to perish. In the fourth stanza, the speaker dares "you" to dance the "inferno tango," a passionate dance of love and fighting, and warns the addressee of "a day darker than night," once again evoking the horrifying aftermath of the bombing of Hiroshima and Nagasaki, a catastrophic consequence the self-obsessed addressee would never have imagined. The speaker's empathy for the vulnerable, their astute insight into the complexities of reality, and their piercing critique of the dominant discourse of the day epitomize the ecofeminist poetics Chen outlined in her essays on and translations of Baudelaire.

\section{Chen's later translations}

In the three decades after the CCP took power in China, from the late $1940 \mathrm{~s}$ to the late 1970s - generally known as the socialist period - Mao Zedong's 
vision of literature and art as subordinate to politics became government policy, with mainstream literary style following on from the sloganistic style of People's Poetry in the 1940s. Chen, like many other intellectuals who held different views of literature, felt compelled to give up her own poetry and concentrate on literary translation. She mainly translated "revolutionary" works from other socialist countries - that is, works that would count as ideologically correct in Mao-era China. However, in July 1957, Chen somehow managed to publish her translations of nine poems by Baudelaire in the prestigious journal Translations (译文). Even though she no longer published her own poetry, her translations enabled Chen to continue her ecofeminist counterbid to "revolutionary literature."

Chen selected, translated, and sequenced the poems (which do not appear successively or in this order in Baudelaire's signature collection The Flowers of Evil [Les fleurs du mal]). In the order in which they were published in Translations, they are "Morning Twilight" (Le Crépuscule du matin), "Evening Twilight" (Le Crépuscule du soir), "The Swan" (Le Cygne), "Death of the Poor" (La Mort des pauvres), "Autumn Sonnet" (Sonnet d'automne), "The Enemy" (L'Ennemi), and the aforesaid "Living Torch," "Spleen IV" and "Evening Harmony." Notably, all these poems - picked by Chen, just like her earlier translations - speak from the perspective of the oppressed and the vulnerable.

Here I focus on the poem that opens the series, Chen's translation of "Morning Twilight," in which her ecofeminist poetics is especially apparent, and which reflects most clearly her use of her agency to speak through the translations. A close reading shows that Chen's modifications and several witting or unwitting mistranslations reflect the ecofeminist poetics she had laid out in "Baudelaire and the Cat" and "My Poetry and Poetry Translation" in the late 1940s.

The French version reads,

La diane chantait dans les cours des casernes,

Et le vent du matin soufflait sur les lanternes.

C'était l'heure où l'essaim des rêves malfaisants

Tord sur leurs oreillers les bruns adolescents;

Où, comme un oeil sanglant qui palpite et qui bouge,

La lampe sur le jour fait une tache rouge;

Où l'âme, sous le poids du corps revêche et lourd,

Imite les combats de la lampe et du jour.

Comme un visage en pleurs que les brises essuient, 
L'air est plein du frisson des choses qui s'enfuient, Et l'homme est las d'écrire et la femme d'aimer.

Les maisons çà et là commençaient à fumer.

Les femmes de plaisir, la paupière livide,

Bouche ouverte, dormaient de leur sommeil stupide;

Les pauvresses, traînant leurs seins maigres et froids,

Soufflaient sur leurs tisons et soufflaient sur leurs doigts.

C'était l'heure où parmi le froid et la lésine

S'aggravent les douleurs des femmes en gésine;

Comme un sanglot coupé par un sang écumeux

Le chant du coq au loin déchirait l'air brumeux;

Une mer de brouillards baignait les édifices,

Et les agonisants dans le fond des hospices

Poussaient leur dernier râle en hoquets inégaux.

Les débauchés rentraient, brisés par leurs travaux.

L'aurore grelottante en robe rose et verte

S'avançait lentement sur la Seine déserte,

Et le sombre Paris, en se frottant les yeux,

Empoignait ses outils, vieillard laborieux.

(Scarfe 1986, 202-203)

Waldrop's translation reads,

Reveille sounded in caserns and a morning wind puffed at the streetlamps.

Hour when swarms of evil dreams set dark adolescents writhing on their pillows; when lamps, like a bloody eye pulsing and beating, make red spots on the day; when the soul, under the harsh and heavy weight of the body, imitates the battle between lamp and daylight. Like a face wet with tears dried by the wind, the air quivers with things in flight, the man weary of writing and the woman of loving.

Smoke began to rise from houses here and there. Women of pleasure, livid eyelids, mouths agape, slept their stupid sleep; beggar-women, dragging meager chilly breasts, blew on half-burned logs and blew on their fingers. Hour when cold and close-fistedness combine to aggravate the pains of women in childbirth; like a sob cut short by turbid blood, a distant cock-crow tore the foggy air; a sea of haze bathed buildings and 
in the back of the poorhouse the dying gave their death rattle in uneven gasps. The debauched went home, broken by their exertions.

Shivering Aurora, in a gown of pink and green, rose slowly over the deserted Seine as gloomy Paris, rubbing eyes, took up its tools, old workingman.

$(2006,135)$

This is Chen's translation:

兵营的院落里响起号角, 街头灯火在晨风中摇曳。

这正是那种时辰: 邪恶的梦好象群蜂

把熟睡在枕上的黑发少年刺痛;

夜灯犹如发红的眼睛, 飘忽、震颤,

给白昼缀上一块红色的斑点,

灵魂载着倔强而沉重的身躯,

模仿着灯光与日光的斗争。

犹如微风吹拂流泪的脸面,

空中充满着飞逝的事物的战栗,

男人倦于写作, 女人倦于爱恋。

远近的房舍开始衰出炊烟,

卖笑的女人, 眼皮青紫,

张着嘴睡得又蠢又死;

那些穷妇人, 垂着消瘦冰冷的乳房,

吹着剩火残灰, 朝手指上呵气。

这正是那种时辰: 在寒冷与穷困当中

劳动妇女的苦难更加深重;

犹如一声鸣咽被翻涌的血流打断,

远处鸡鸣划破了朦胧的空间;

一片雾海淹没了所有的建筑,

那些苦人在收容所的深处

打着呃，喘着最后的一口气。

游荡得筋疲力尽的浪子走回家去,

晨羲抖索地披上红绿的衣裳，

沿着寂寞的塞纳河徐徐漫步;

暗淡的巴黎, 睡眼朦胧,

一手抓起工具, 象个辛勤劳动的老人。 
The first adjustment Chen makes is in the title. By rendering this as "Hazy Dawn” (朦胧的黎明) rather than “Morning Twilight," as other translators do, Chen narrows the focus from the twilight to the brief moment before dawn, a moment of liminality, just before night yields to daylight. This shift is reinforced by another change Chen makes in the second stanza. Rather than following the syntactic structure and translate l. 1 as "it was the hour when" as Scarfe does (202) or "hour when" as Waldrop does (135), Chen separates "it was the hour" from the rest of the line, emphasizing this with a colon and by adding "precisely" (正). She makes the same change in the next stanza when the sentence is repeated. Moreover, she makes a rare formal change, by removing the break between the third and fourth stanzas. The poem's concluding lines thus lose the prominence they have in the source text, and the poem's center of gravity shifts to the critical moment before dawn, foregrounded by the adjusted title and the repeated emphases on "the hour" in stanzas 2 and 3 .

What is the significance of this particular moment? With the restructuring of the stanzas, the brief first stanza, a single couplet depicting the pre-dawn moment, gains in prominence. As in some of his other poems, such as "Music," Baudelaire uses the opposition of night and day to symbolize the struggle between body and soul. For Baudelaire, the daylight, heralded by the call of the military bugle in the caserns, signifies hope and enlightenment of the soul. On the other hand, the light from the streetlamp, representing the vanishing night, symbolizes the soon-to-be defeated hindering body. Chen, however, whose earlier translation of "Music" replaces the image of a conflict of body and soul with one of the pursuit of freedom, changes the dynamic between body and soul again in "Morning twilight" and infuses her translation with another new meaning. Unlike Waldrop, who adheres to Baudelaire's original syntax and highlights the agency of the morning wind, Chen emphasizes the persistence of the streetlight. In English translation, her version reads, "In the barracks courtyard bugles start to sound, / Streetlights sway in the morning wind." For that moment, the quiet, quavering pre-dawn lamplight on the street, continues its delicate existence despite the nudging of the morning wind.

This shift of the dynamic between body and soul is most visible in Chen's translation of $11.5^{-6}$ in the second stanza. Scarfe's and Waldrop's translations convey the conflict between the speaker's body and soul through the struggle of night and day, presenting the body as a negative, oppressive force that prevents the soul from achieving transcendence. Chen, on the other hand, presents the body in a positive light as a tired but persistent partner of the soul in their struggle against the daylight: "The soul, carrying the adamant 
and heavy body, / imitates the battle between lamplight and daylight." The word rendered here as "adamant" (倔强) often describes positive qualities such as perseverance in the face of hardship; "heavy" (沉重), appearing together with "adamant," takes on a more positive meaning too, by signifying the physical exhaustion that results from persistent endeavor.

The third stanza highlights the suffering of the poor, especially poor women. In ll. 2-7, we see merciless, heart-wrenching images of suffering women at the bottom of society, recalling Chen's statement about Baudelaire's empathetic love of the vulnerable in "Baudelaire and the Cat." Chen's translation reads,

The woman who sells her laughs, with eyelids black and blue, Mouth open, sleeps like an idiot and as if dead;

Those poor women, with emaciated and ice-cold breasts hanging low, Blow at what remains of the fire and the ashes, breathe on their fingers. It is precisely that kind of hour: in the cold and in poverty The suffering of the laboring women grows ever graver;

Chen substantially diverges from the source text in two places. She mitigates Baudelaire's misogynist depiction of the prostitute sleeping "stupidly" by adding that she is asleep "as if dead" (死) - a standard Chinese expression for sleeping deeply - thus hinting at her exhaustion from a tough life. Secondly, she translates "des femmes en gésine" (of the women in labor) as "of the laboring women” (劳动妇女). This appears to be a (remarkable) error; as Chen also read English, it is possible that it reveals a misreading of the phrase "women in labor." Be that as it may, Chen's word choice replaces a specific kind of suffering by women - the excruciating pain of giving birth - with what she may have seen as a more universal kind of suffering rooted in history, culture, and politics, i.e. the oppression of women at large. Further, the Chinese expression “laboring women" (劳动妇女), a Marxist term for proletarian women widely used during the socialist era, is in accordance with the political environment of the time when the translations were published, and potentially enabled Chen to avoid political persecution. At any rate, "in the cold and in poverty / The suffering of the laboring women grows ever graver" echoes Chen's reference to the exacting circumstances of her own marriage with Sha Lei from 1940 to 1945, and her subsequent observation of the continued oppression of women in modern times (Chen 1947, 7). The resonance of this poem with Chen's experience of suffering and struggle in a male-dominated society and literary field may have been among the reasons why Chen chose "Morning Twilight" as the lead poem in the series published in Translations. 
Chen's own experience of suffering and oppression as a woman, though often compartmentalized as personal misfortune and dismissed as trivial in comparison to her male colleagues' grand discourses of nation, revolution, and class (Tang 2003, 113, 118; Jiang 2006, 31), enabled her to have a profound sensitivity and empathy for the ugly underbelly of society - to which her male counterparts were often blind, both during the civil war and in later years. Baudelaire-à-la-Chen's images of suffering women display a sharp contrast with the idealistic portrayal of empowered rural women in the statesponsored writing of the socialist period. Chen's translation of Baudelaire stubbornly points to a dark side of reality ignored by this propagandistic literature, as the oppression of women, the poor, and other vulnerable groups continued under the new regime, despite its grand discourse of equality for all.

\title{
Conclusion
}

Until her death in 1989, Chen Jingrong never had the opportunity to meet with or learn about the advocates of ecofeminism, feminist translation, and translator agency who were making waves in the West. Throughout her life she searched alone for ways to communicate her prescient observations and her critique of the male-dominated political, cultural, and literary environment in China. As Greta Gaard writes, “Ecofeminists use 'resilience' as a word that means taking survival - and the eco-ethics and community this survival requires - into our own hands" (2018, xv). Chen did exactly what Gaard envisions an ecofeminist doing, in her creative interpretation and translation of Baudelaire, and in her own poetry. She underscored the agency of the reader/translator, amplified the resilient strength of the speaker in Baudelaire's poetry, and made a case for the power of empathy.

In 1978, after a thirty-year silence due to the CCP's restrictive policy on literature, Chen started writing poetry again in a small ground-floor apartment on a busy street in Beijing. "Sour Fruit" (酸果), the first of a series of four poems titled "My Seventy" (我的七十) written around Chen's seventieth birthday, is a perfect summary of her signature perspective:

\author{
没有嫩绿鲜红 \\ 流水哗哗 \\ 漫过堤岸而去 \\ 日月的光华 \\ 照耀众多树木 \\ 偶尔也酒上荆从
}


酒上默默的酸果

酸涩与苦咸

浸透了果肉果壳

果核却无比坚硬

如石

如钢铁

原本是由铁水浇铸而成

在钢铁基座上

它被赋予了

多汁的甘美果肉

那吐着青色光焰的

依旧是粗粮的果壳

(Luo and Chen 2008, 532-533)

there is no tender green nor fresh red

the flowing water gurgles

brims over the bank and is gone

the splendors of the sun and the moon

shine on numberless trees

and occasionally glint on the thorny bushes

and on the silent sour fruit

acrid sour and bitter saltiness

have permeated its flesh and shell

yet the pit of the fruit is harder than ever

like stone

like iron

it was molded from liquid iron

on the top of the iron base

it was bestowed with

juicy sweet flesh

what is emitting an electric blue radiance

is still its coarse shell

(Meng 2015, 17)

Contemplating her life at the age of seventy, Chen compares herself to the sour fruit, an inconspicuous but hardy plant that can survive without much water, 
light, or care. The metaphor sets Chen apart from the male-dominated field of Chinese poetry in the 1980s, where women are overwhelmingly portrayed as young, beautiful, gentle, and in need of protection. Chen further stresses her uncommon position in the poem's opening line. With a firm negation, she makes it clear that a woman like herself does not have the qualities deemed desirable in the stereotype - no eye-catching youthful beauty, no fresh and delicate tenderness. The rest of the first stanza depicts the neglect the sour fruit suffers in the harsh wilderness. It is near the river, but the water "brims over the bank" and flows away, instead of lingering and nourishing it. The sun and moon generously shine on "numberless" taller trees, but only "occasionally glint on the thorny bushes" where the sour fruit grows in silence.

In the second stanza, the poet first draws attention to the impact of life's sufferings on the sour fruit but proceeds to emphasize the plant's toughness and perseverance. The comparisons of the sour fruit to rock and iron in the second and third stanzas might be reminiscent of the "Iron Girl" image of socialist-era propaganda literature; rather than conveying blind optimism and youthful strength, however, Chen's sour fruit underscores persistence and resilience in the face of adversity.

The sour fruit, a plant with no tender green leaves or fresh red flowers, is soaked with the sourness and saltiness of life's sufferings. Its core, though, is as hard as stone and iron. Its shell is coarse but radiant with fire. Tenacity is what enabled the poet to sustain her life-long search for what retrospectively manifests itself as a distinctly ecofeminist poetics that reflects profound empathy for the vulnerable and prescient insight into the catastrophic consequences when this is replaced by the reckless pursuit of power.

\section{Works cited}

Babaee, Ruzbeh. 2016. "Translation and Creative Writing: An Interview with Professor Margaret Rogers." International Journal of Comparative Literature and Translation Studies 4 (1): 1-3.

Bai Hua 柏桦. 2009. 〈始于1979- 比冰和铁更刺人心肠的欢乐〉 [Starting in 1979: A pleasure more piercing to the heart than ice and iron]. In 《七十年 代》 [The seventies], edited by Bei Dao 北岛 and Li Tuo 李陀, 539-540. Beijing: Shenghuo dushu xinzhi sanlian shudian.

Bei Dao 北岛. 2005. 《时间的玫瑰: 北岛随笔》 [The rose of time: essays by Bei Dao]. Beijing: Zhongguo wenshi chubanshe.

Bian Zhilin 市之琳. 2000. 《六之琳译文集 (中卷)》[Translations by Bian Zhilin, vol. 2]. Hefei: Anhui jiaoyu chubanshe. 
Bien, Gloria. 2013. Baudelaire in China: A Study in Literary Reception. Newark: University of Delaware Press.

Chen Jingrong 陈敬容, trans. 1946a. Charles Baudelaire. 〈音乐〉(La Musique) [Music]. 《文汇报.笔会》96, November 15 .

一, trans. 1946b. 〈波德莱尔与猫〉 [Baudelaire and the cat]. 《文汇报.笔会》, December 19 .

一. 1947. 〈谈我的诗和译诗〉 [On my poetry and poetry translation]. 《文汇报. 笔会》, February 7: 7.

一, trans. 1984. Charles Baudelaire and Rainer Maria Rilke. 《图像与花朵》

[Images and flowers]. Changsha: Hunan renmin chubanshe.

Dai Wangshu 戴望舒. 1983. 《戴望舒译诗集》 [Dai Wangshu's poetry translations]. Changsha: Hunan renmin chubanshe.

Denton, Kirk A. 2016. “Literature and Politics: Mao Zedong's 'Yan'an Talks' and Party Rectification." In The Columbia Companion to Modern Chinese Literature, edited by Kirk A. Denton, 224-230. New York: Columbia University Press.

Gaard, Greta. 2016. "From 'cli-fi' to critical ecofeminism: narratives of climate change and climate justice." In Contemporary Perspectives on Ecofeminism, edited by Mary Philips and Nick Rumens, 169-192. London and New York: Routledge.

—. 2018. "Foreword." In Literature and Ecofeminism: Intersectional and International Voices, edited by Douglas A. Vakoch and Sam Mickey, xiv-xvi. London and New York: Routledge.

Jiang Dengke 蒋登科. 2002. 《九叶诗派的合璧艺术》 [The Nine Leaves poetry school's art of fusion]. Chongqing: Xinan shifan daxue chubanshe.

-.2006. 《九叶诗人论稿》 [Essays on the Nine Leaves poets]. Chongqing: Xinan shifan daxue chubanshe.

Li Baifeng 李白凤. 1947. 〈从波德莱尔的诗谈起〉 [A few words on Baudelaire's poetry]. 《文汇报》, January 30: 7 .

Liang Xiaoming 梁晓明. 2006. 〈多多访谈〉 [An interview with Duo Duo]. 《中国 诗刊》1. bit.ly/2U3ZMbk. Accessed August 21, 2018.

Lin Huanping 林焕平. 1946. 〈波德莱尔不宜赞美〉 [It is inadvisable to praise Baudelaire]. 《文汇报》, December 28.

Ling Yue 凌越. 2004. 〈我的大学就是田野 - 多多访谈录〉 [The great outdoors is my university: an interview with Duo Duo]. In Duo Duo 多多, 《多多诗选》 [Selected poems by Duo Duo], 266-293. Guangzhou: Huacheng chubanshe.

Liu Zhirong 刘志荣. 2015. 〈“文革” 中读波德莱尔 - 红色年代里的隐秘阅读 史〉 [Reading Baudelaire during the Cultural Revolution: the secret history of reading during the Red Years]. 《财经》, May 24.

Luo Jiaming 罗佳明 and Chen Li 陈俐, eds. 2008. 《陈敬容诗文集》 [Poetry and prose of Chen Jingrong]. Shanghai: Fudan daxue chubanshe. 
Meng, Liansu, trans. 2015. Chen Jingrong 陈敬容. “My Seventy (No. 1: Sour Fruit)” (〈我的七十 (一: 酸果) 〉). In Chinese Literature Today 5 (1): 17 .

Mickey, Sam. 2018. "Editor's Preface." In Literature and Ecofeminism: Intersectional and International Voices, edited by Douglas A. Vakoch and Sam Mickey, xvii-xiv. London and New York: Routledge.

Palacios, Manuela. 2014. "Translation in the Feminine: Theory, Commitment and (Good) Praxis." Women's Studies International Forum 42: 87-93.

Palmary, Ingrid. 2014. "A Politics of Feminist Translation: Using Translation to Understand Gendered Meaning-Making in Research.” Signs 39 (3): 576-580.

Perteghella, Manuela and Eugenia Loffredo, eds. 2007. Translation and Creativity: Perspectives on Creative Writing and Translation Studies. London: Continuum. Quandt, Karen F. 2015. "Baudelaire and the Poetics of Pollution." Dix-Neuf 19 (3): 244-259.

Rosario, Nelly. 2012. "Seeing Double: Creative Writing as Translation." Callaloo 35 (4):1001-1005.

Scarfe, Francis, edit and trans. 1986. Charles Baudelaire. Baudelaire: The Complete Verse. London: Anvil Press.

Song Mingwei. 2015. Young China: National Rejuvenation and the Bildungsroman, 1900-1959. Cambridge, MA: Harvard University Asia Center.

Tamburello, Giusi. 2012. "Baudelaire's Influence on Duo Duo's Poetry through Chen Jingrong, a Chinese Woman Poet Translating from French.” Asian and African Studies 16 (2): 21-46.

Tang Shi 唐湜. 2003. 《九叶诗人: 中国新诗的中兴》 [The Nine Leaves poets: the resurgence of Chinese New Poetry]. Shanghai: Shanghai jiaoyu chubanshe.

Tie Ma 铁马. 1946. 〈略论陈敬容的诗 - 读了他致一个陌生读者的信以后的感 想〉 [A brief note on Chen Jingrong's poetry - thoughts after reading his letter to an unfamiliar reader]. 《文汇报》, December 30.

van Crevel, Maghiel. 2017. "Walk on the Wild Side: Snapshots of the Chinese Poetry Scene.” MCLC Resource Center. bit.ly/2GaWWhc. Accessed August 6, 2019.

Waldrop, Keith, trans. 2006. Baudelaire. The Flowers of Evil. Middletown: Wesleyan University Press.

Wang Shengsi 王圣思, ed. 1995. 《“九叶诗人”评论资料选》 [Selected critical materials on the "Nine Leaves Poets"]. Shanghai: Huadong shifan daxue chubanshe.

Weinbaum, Alys Eve. 2003. "Ways of Not Seeing: (En)gendered Optics in Benjamin, Baudelaire, and Freud." In Loss: The Politics of Mourning, edited by David L. Eng and David Kazanjian, 396-426. Oakland: University of California Press.

Wen Aiyi 文爱艺, trans. 2007. Baudelaire. 《恶之花》 [The flowers of evil]. Chengdu: Sichuan renmin chubanshe. 
You Youji 游友基. 1997. 《九叶诗派研究》 [Studies on the Nine Leaves poetry school]. Fuzhou: Fujian jiaoyu chubanshe.

Zhang Songjian 张松建. 2009. 《现代诗的再出发: 中国四十年代现代主义诗 潮新探》 [The re-emergence of modern poetry: a new inquiry into modernist poetry in 1940s China]. Beijing: Beijing daxue chubanshe.

Zhou Xuliang 周煦良, ed. 1979. 《外国文学作品选》 [Selections of foreign literature]. Shanghai: Shanghai yiwen chubanshe.

Zou Zhenhuan 邹振环. 1996. 《影响中国近代社会的一百种译作》 [One hundred translated works that influenced modern Chinese society]. Beijing: Zhongguo duiwai fanyi chuban gongsi.

\section{About the author}

Liansu MENG is associate professor of Chinese at the University of Connecticut. Her research interests include modern and contemporary Chinese poetry, unofficial literary magazines, translated literature, Chinese feminism, gender and technology, ecofeminism, ecopoetics, transnational poetics, and comparative poetics. She has published articles on ecopoetics and transnational poetics in modern Chinese poetry. Her monograph Man/Woman, Machine/Nature: Modern Chinese Poetry at the Intersection of Industrialism and Feminism (1915-1980) is forthcoming at the University of Michigan Press. 